DOI: 10.17707/AgricultForest.62.4.20

Mile MARKOSKI, Tatjana MITKOVA, Vjekoslav TANASKOVIK, Velibor SPALEVIC and Zeljka ZGORELEC ${ }^{l}$

\title{
THE INFLUENCE OF THE PARENT MATERIAL ON THE TEXTURE AND WATER RETENTION CURVES IN THE SOIL FORMED UPON LIMESTONES AND DOLOMITES
}

\begin{abstract}
SUMMARY
The paper present results from the research of the influence of the parent material on the soil texture and water retention curves of Rendzic Leptosols. Chromic Luvisol on hard limestones and Ferric Luvisol on hard limestones Terra Rossa. The contents of the fine soil separates in the Rendzic Leptosols vary depending on the subtype. The physical sand fraction (coarse sand + fine sand) in the Amo horizon amounts $44.81 \%$ at the Rendzic Leptosols, haplic $40.13 \%$ at the Rendzic Leptosols-organogenic and Rendzic Leptosols, chromic luvic 36.52\%. In the (B)rz horizon at the Rendzic Leptosols, chromic luvic amounts $32.64 \%$. The contents (clay + silt) or physical clay in the Amo horizon amounts $55.19 \%$ at the Rendzic Leptosols, haplic 59.87\% at the Rendzic Leptosols, organogenic and the highest content is at the Rendzic Leptosols, chromic luvic 63.48\%. The average value of this fraction in the horizon (B)rz at the Rendzic Leptosols, chromic luvic amounts $67.36 \%$. In the Chromic Luvisol on hard limestones the average content of the fraction physical sand in the Amo horizon amounts $33.43 \%$, and in the cambic horizon (B)rz 22.50\%. At the Terra Rossa the fraction physical clay is represented with a greater percentage related to the physical sand fraction. In the Amo horizon in the physical clay fraction the clay fraction is predominant, average $43.08 \%$ and $52.13 \%$ in the cambic horizon, i.e. $24.90 \%$ in Amo and $19.37 \%$ for the silt fraction. There is the highest retention capacity, with the average of $41.48 \%$ in the humus-accumulative horizon Amo in the Rendzic Leptosols subtype organogenic. The remaining subtypes of Rendzic Leptosols have lower retention capacity in this horizon. As with retention capacity of 0.33 required in other points of tension (6.25 and 15 bar) shows the same condition (mean value have Rendzic Leptosols organogenic (29.39 and $17.22 \%$ respectively), then Rendzic Leptosols, haplic (23.98 and $18.34 \%$ respectively) and Rendzic Leptosols, chromic luvic (21.70\% and $16.60 \%$ respectively). The average retention values in the Amo horizon and the cambic horizon (B)rz regarding Chromic Luvisol on hard limestones amounts to $33.49 \%$ i.e. $33.24 \%$. The average retention values (pressure of 6.25 and 15 bar) in the

\footnotetext{
${ }^{1}$ Mile Markoski (corresponding author: mile_markoski@yahoo.com), Tatjana Mitkova, Vjekoslav Tanaskovik, Faculty of Agricultural Sciences and Food, University "Ss. Cyril and Methodius" Blvd. Aleksandar Makedonski bb., Skopje, MACEDONIA; Velibor Spalevic, University of Montenegro, Faculty of Philosophy Niksic, Department of Geography, MONTENEGRO; Zeljka Zgorelec, Faculty of Agriculture, University of Zagreb, CROATIA.

Notes: The authors declare that they have no conflicts of interest. Authorship Form signed online.
} 
Amo horizon and the cambic horizon (B)rz regarding Chromic Luvisol on hard limestones amounts to $(25.27 \%$ and $17.06 \%$ respectively) i.e. $(27.89 \%$ and $16.68 \%$ respectively). The average retention capacity in Terra Rossa, amounts to $39.05 \%$ in the Amo horizon, and $40.25 \%$ in (B)rz. The average retention values (pressure of 6.25 and 15 bar) in the Amo horizon and the cambic horizon (B)rz regarding Terra Rossa amounts to $(29.92 \%$ and $20.93 \%$ respectively) i.e. (33.23\% and $23.38 \%$ respectively). The results from our research show that in Amo and (B)rz horizon there is a positive correlation between the water retention curves at $0.33 ; 6.25$ and 15 bars and contents of physical clay (clay and silt) and clay. There is also a high negative correlation between the retention curves at $0.33 ; 6.25$ and 15 bars contents of physical sand fraction (coarse sand + fine sand; $r=-0.47)$.

Key words: Soil, water retention, texture, limestones, dolomites.

\section{INTRODUCTION}

The soils formed on limestones and dolomites can be found in all mountain regions and regions which are fully or partially composed of limestones. It can be said that these soils are present on almost all continents due to their connection with the parent material. (Kochkin, 1967; Plaster et al. 1971; Bronger. et al. 1981; Bronger. et al. 1983). The hydrous and physical relations. in addition to the mineralogical composition of the soil, are also influenced by the mechanical content. Various researchers studied the content of organic matter (Hillel, 1980; Maclean and Yager, 1972; Jamison and Kroth, 1958; Shaykewich and Zwarich, 1968; Heinonen, 1971) and the influence of organic matter and the mechanical composition over the retention of moisture in several different soils in the USA, Europe and Asia. In the research of Hollist et al. (1977) it is confirmed that the soil moisture retention in Western Midland (Great Britain) depends mainly on the organic matter and mineralogical composition of soil. According to (Warkentin \& Meada, 1974, 1975; Rausseaux \& Warkentin, 1976), the retention of moisture at different tensions is strongly correlated with the content of humus, clay, silt and the mineralogical composition of the clay.

The hydro physical properties of soils is the water retention and the water permeability in the saturated and unsaturated zone, not only affect the water balance but also have a dominant influence on the conditions of growth and development of plants. They determine the availability of water to plants and leaching of nutrients dissolved to the deeper layers of the soil (Coquet et al. 2005; Hillel. 1998. Kutilek and Nielsen. 1994). The knowledge of the hydrophysical properties of the soil is therefore essential in the interpretation and prediction of changes of the vegetation cover, which occur as a result of a natural succession.

The intensity of the impact of the mechanical composition on the retention of soil moisture depends on the share of certain fractions of soil separates and the percentage. Particles of clay, due to the large inner and outer active surface, high cation exchange capacity (CEC) and mineralogical composition, represent the 
most active fraction of the mechanical composition of the soil (Škorić. 1991). In our research, the main emphasis is on the dependence and impact of mechanical composition on the retention of water in the surveyed Rendzic Leptosols, Chromic Luvisol on hard limestones and Terra Rossa in the Republic of Macedonia. Due to the mentioned importance of the mechanical composition and organic matter of the other properties of soil, this paper investigates the impact on retention of soil moisture at different points of tension, ranging from 0.33 up to 15 bars, which correspond to the water constant, which is called permanent wilting point (PWP). The remaining moisture above 15 bars is unavailable to plants (Markoski. 2013).

\section{MATERIAL AND METHODS}

Field researches have been carried out for the soils formed on limestones and dolomites, on various locations on the territory of the Republic of Macedonia. Locations for the opening of the pedological profiles (a total of 52, out of which 34) are: Rendzic Leptosols (FAO Classification, 1988), WRBRendzic Leptosol (WRB classification, 2006); 13 Chromic Luvisol on hard limestones (FAO Classification, 1988), (WRB-Chromic Leptic Luvisol on hard limestones) (WRB classification 2006), and 5 profiles of Ferric Luvisol on hard limestones - Terra Rossa. WRB-Rhodic Leptic Luvisol on hard limestones (FAO Classification, 1988), (WRB CLASSIFICATION 2006). The field research was carried out standard soil science methodologies. The mechanical composition of the soil is determined according to the international A-method (Singh et al. 1999; Kadam. J. R. et al 2005).

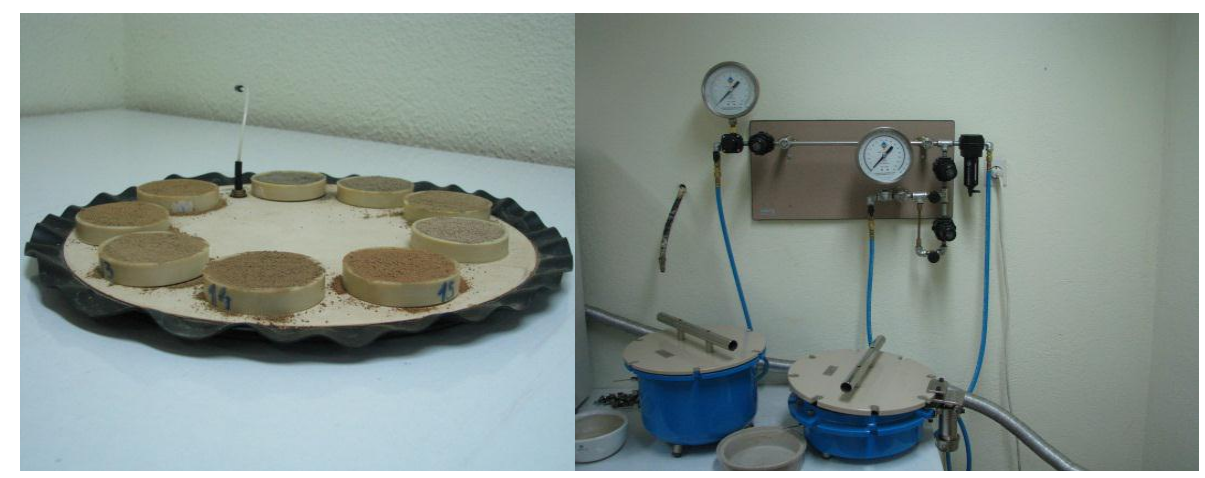

Figure 1. Preparing soil and placing samples on

Bar extractor and Porous plate extractor

The fractioning of the mechanical elements has been performed according to the International Classification; the classification of the soils in texture classes has been performed according to the American triangle (Bormann, 2007; Christopher and Mokhtaruddin, 1996). The determination of moisture retention at a pressure of 0.33 bar (pF-2.54) and 1 bar (pF-3), was performed by a method of applying pressure with a Bar extractor. To determine the retention of soil 
moisture at higher pressures, the method of Richards (1982), Porous plate extractor): 2.0 bar (pF-3.3); 6.25 bar (pF-3.90); 11 bar (pF-4.04) and 15 bar (pF4.2).

An analysis of variance (ANOVA) has been made for samples of various sizes, for all analysed properties in both horizons. The influence of the substrate, the soil type and their interaction on the variability of all examined properties has been determined. The importance of the differences among the mean values of the analysed properties, for each parent material and soil type separately, has been determined with the Tukey test, for level $p<0.05$. All statistical analyses have been made with the software package R.

\section{RESULTS AND DISCUSSION}

The mechanical composition of the soils formed on limestones and dolomites varies extensively and depends on the mechanical composition of the residuum from which the mineral part of the soil is composed, on the character of the limestone and the dolomite (the degree of weathering), on the deposition of nearby materials (from the higher fields) and on the degree of erosion (Yaalon and Ganor, 1973; Jackson, et al., 1982; Mizota, et al., 1988; Borg and Banner, 1996; (Durn, et al., 1999; Durn, 2003; Muhs and Budahn, 2008). Chart 1 contains an overview of the parent materials on which Rendzic Leptosols, Chromic Luvisol on hard limestones and Terra Rossa are formed.

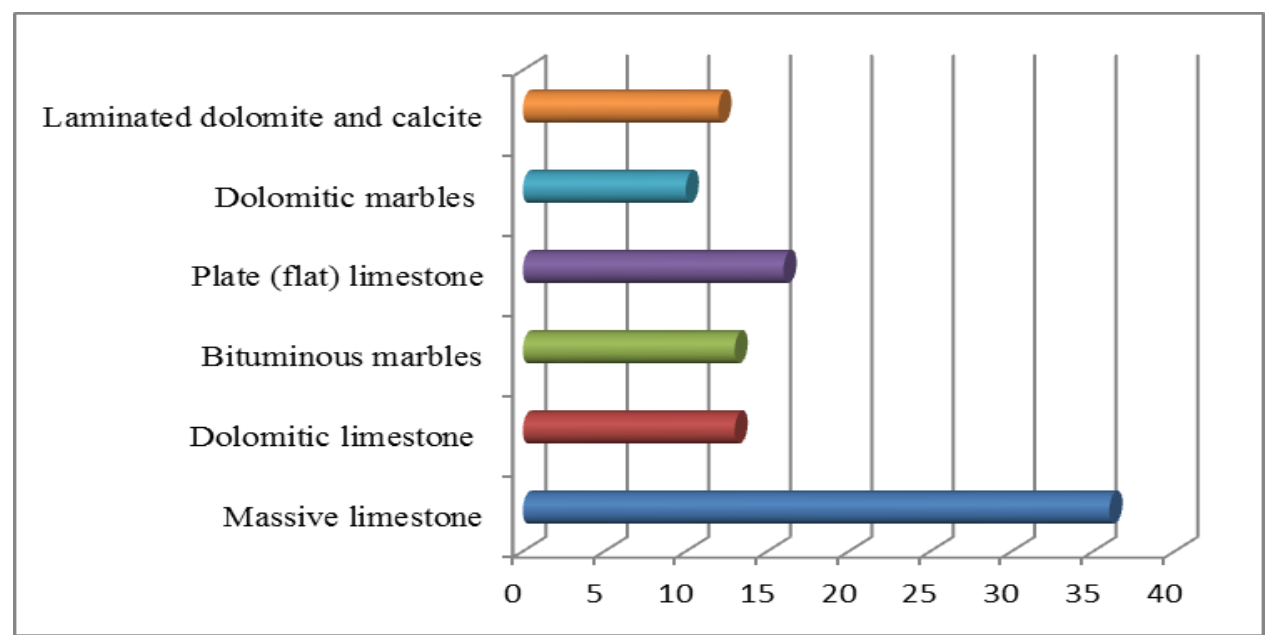

Chart 1. Parent materials on which Rendzic Leptosols. Chromic Luvisol on hard limestones and Ferric Luvisol on hard limestones Terra Rossa are formed

The chart shown that $36 \%$ of the soils are formed on massive limestone; $13 \%$ on dolomitic limestone and bituminous marbles; $16 \%$ on Plate (flat) limestone; $10 \%$ on dolomitic marbles; and $12 \%$ on laminated (plate) dolomite and calcite. On the basis of the above, it can be confirmed that the soils are formed from horn slate - hornfels facies and their composition has an influence 
on the mechanical composition. This facia has a thickness of around $500-550$ $\mathrm{m}$, it is composed of dolomites, plate (flat) limestone with hornfels and massive limestone, and it represents a continuation in Anisian and Ladinian, and it strongly reflects on the morphology, the physical and physical-mechanical properties, water retention curves, the mineral composition and the chemical properties of the soils.

It also depends on the processes which take place within these soils during their paedogenesis and evolution, and which cause the texture differentiation. In order to have better understanding, hereunder are given the mean values for each fraction of the fine earth of the examined soils, by type, subtype and horizon. Table 1 and Table 2.

The content of particular fraction of the fine earth in Calcomelanosols varies depending on the subtype. The physical sand fraction (coarse sand + fine sand) in the Amo horizon amounts $44.81 \%$ at Rendzic Leptosols, haplic, $40.13 \%$ at Rendzic Leptosols organogenic and $36.52 \%$ at Rendzic Leptosols, chromic luvic. In the (B)rz horizon at the Rendzic Leptosols, chromic luvic it amounts $32.64 \%$.

The content of physical clay fraction (clay + silt) in the Amo horizon amounts 55.19\% at the Rendzic Leptosols, haplic 59.87\% at the Rendzic Leptosols, organogenic, and the highest content is found at the Rendzic Leptosols, chromic luvic $63.48 \%$. The mean value of this fraction in the horizon (B)rz at the Rendzic Leptosols, chromic luvic amounts $67.36 \%$. In all profiles of Chromic Luvisol on hard limestones, the fine earth predominates over coarse.

In the fine earth, the physical clay fraction in both horizons, Amo and (B)rz is present as twice as more than the physical sand fraction. The average content of the physical sand fraction in the Amo horizon amounts $33.43 \%$, and in the cambic horizon (B)rz 22.50\%. At the Terra Rossa, the physical clay fraction is present in a greater percentage in relation to the physical sand fraction. At the same time, the physical clay fraction in the Amo horizon is predominated by the clay fraction, $43.08 \%$ in average and $52.13 \%$ in the cambic horizon, i.e. $24.90 \%$ in Amo and $19.37 \%$ for the silt fraction.

The differences in the mechanical composition are confirmed with the descriptive statistics and the analysis of variance made for each type, subtype and horizon. The analysis of variance demonstrated that in both horizons, the soil type has an important influence over the variability of the content of coarse, silt and the total content of clay. In the Amo horizon, the soil type has influence both over the physical sand fraction and the physical clay fraction.

The data on the mechanical composition of the examined soils formed on limestones and dolomites are similar to the data for these soil types presented by other authors: (Maric, 1964; Durn. 2003; Delgado. et al. 2003).

When it comes to the impact of the subsoil (limestone and dolomite) on the mechanical composition of the soil, care should be taken, because the soil is formed only from residual and it has the same mechanical composition in all locations on the same wall. 
Table 1. Mean values for the mechanical composition of the soils in the Amo horizon

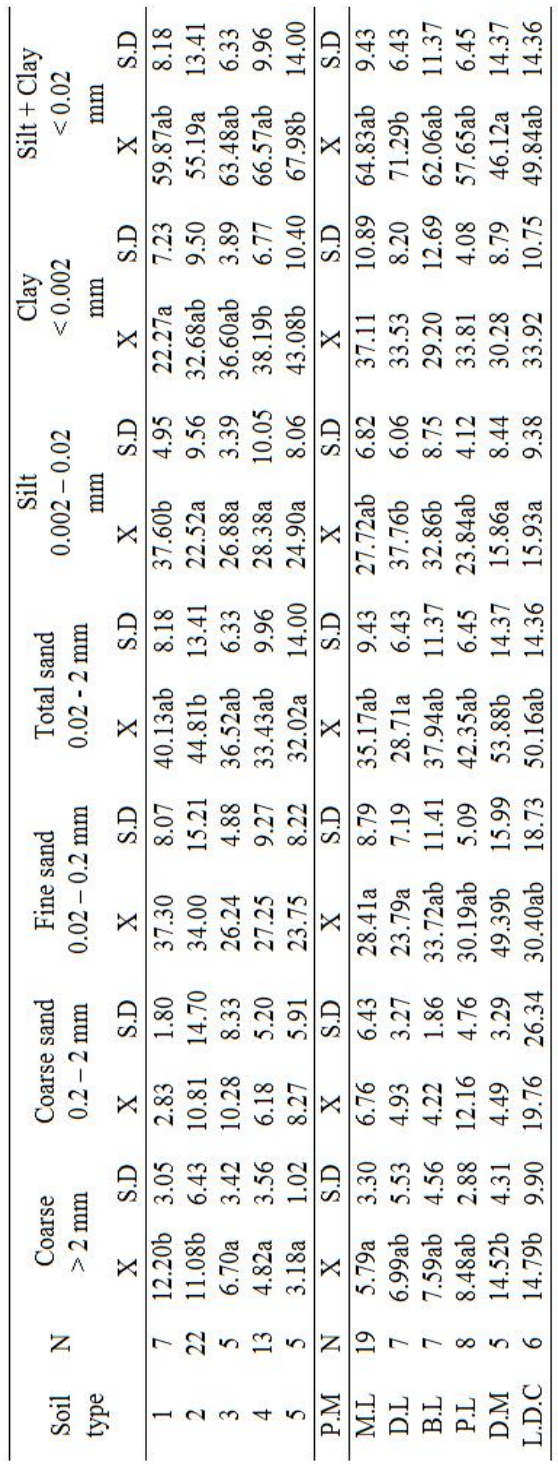

1. Rendzic Leptosols -organogenic; 2. Rendzic Leptosols, haplic; 3. Rendzic Leptosols, chromic luvic; 4. Chromic Luvisol on hard limestones; 5. Terra Rossa. P.M- Parent material; M.L.-Massive limestone; D.L-dolomitic limestone; B.Lbituminous Limestone; P.L-Plate limestone; D.M. Dolomitic Marbles; L.D.C- laminated (plate) dolomiteand calcite
The author (Markoski, 2013) found at two locations of massive limestone that residual has 17.2 and $30.2 \%$ secondary phyllosilicates (clay). In Tables 3 profiles are grouped according to texture classes for each of the parent substrate for both horizons.

For horizon Amo it can be concluded that 6 stem parent materials all have 4 textural classes, 2 of them have 3 classes and 1 has two textural classes. From Table 3 it can be seen that the horizon (B)rz is found in a small number of profiles, in most clay it is in mechanical composition.

(Ćorić. 2009) has an interesting consideration regarding the homogeneity of the textural classes in the formation of Terra Rossa.

He points out that the content of certain categories of particles in the homogenous soils, as Terra Rossa, should be indicated on the autochthony of the texture categories and simultaneously, it is a confirmation that the same has been formed at that place. On the contrary, if these categories are not homogenous, it means that the soils have polygenetic characters, and that the solum has a depositing character.

Water is one of the five environmental factors for normal growth and development of the plant, and it has strong influence on the quality and stability of the crop yield.

The retention of water in the soil is the result of two forces: adhesion (attraction of water molecules by soil particles) and cohesion (water molecules attract each other). Adhesion is much stronger than cohesion. 
Table 2. Mean values for the mechanical composition of the soils / horizon (B)rz

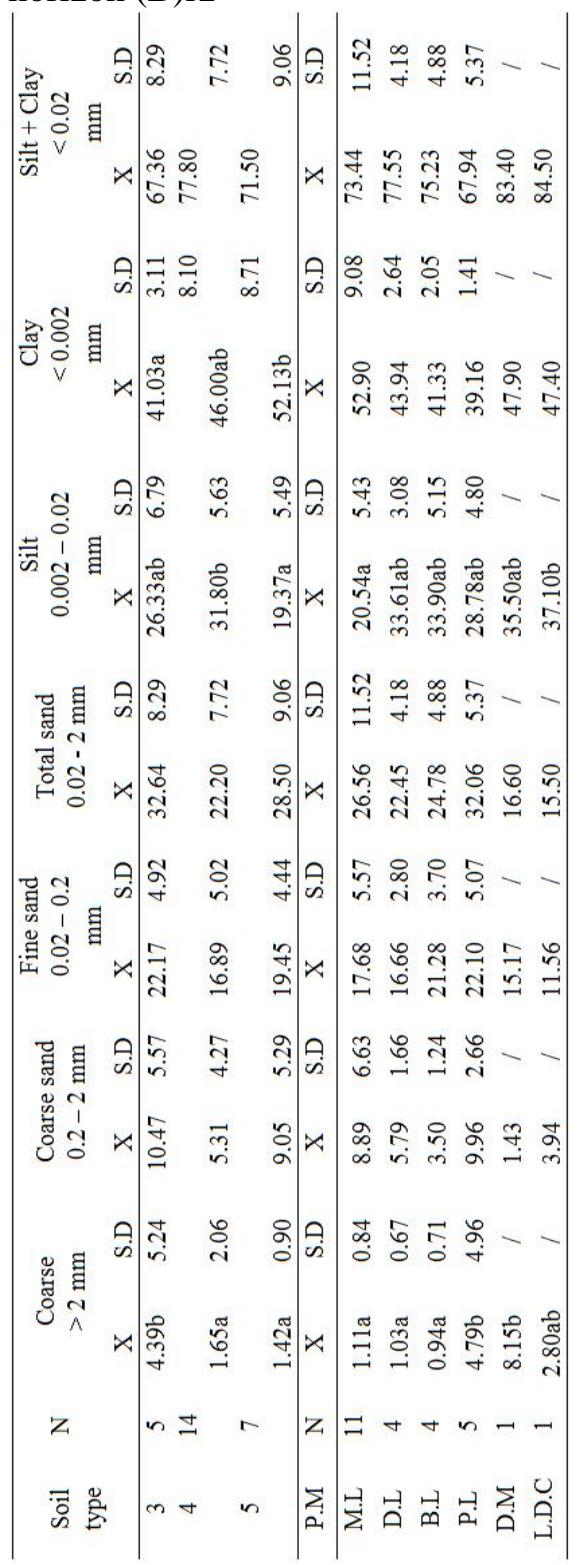

3. Rendzic Leptosols, chromic luvic;

4. Chromic Luvisol on hard limestones;

5. Terra Rossa;P.M- Parent material; M.L.-

Massive limestone; D.L-dolomitic limestone;

B.L- bituminous Limestone; P.L-Plate limestone; D.M. Dolomitic Marbles; L.D.Claminated (plate) dolomiteand calcite
The force with which water is retained in the soil is called capillary potential and is closely related to water content. Free water in the soil has capillary potential equal to zero, a condition when all the soil pores, capillary and non-capillary, are filled with water.

Earlier we pointed out that the mechanical composition (texture), water retention curves of the soils formed on limestones and dolomites depends both on the material, as well as the soil type i.e. pedogenesis and evolution. The differences in mechanical composition and statistical justification of the above can be best seen from the descriptive statistics and variance analysis made according to types, subtypes, horizons and parent material on which the soils are formed (Table 4) which is also the conclusion from our research.

Soil water potential can be determined indirectly by recourse to measurements of soil water content and soil water release or soil moisture characteristic curves that relate volumetric or gravimetric content to soil water potential. The measurement of water potential is widely accepted as fundamental to quantifying both the water status in various media and the energetics of water movement in the soil-plant-atmospheric continuum (Livingston, 1993; Markoski 2013) pointed out that by reducing the moisture content in the soil, the value of the capillary potential is increasing. For assessment of soil moisture by means of capillary potential, quantified by Schofield (Vucić, 1987), it was suggested $\mathrm{pF}$ values, where the force of water in the soil was expressed by the 
soil was expressed by the height of the water column in $\mathrm{cm}(1 \mathrm{bar}=1063 \mathrm{~cm}$ water $/ \mathrm{cm}^{-2}$ ). The $\mathrm{pF}$ values are affected by the change of the mechanical composition and. according to the same author, the greater the share of the smaller fractions, the greater the $\mathrm{pF}$ values, especially at a pressure of 0.33 bars.

Table 3. Texture classes in horizon Amo and (B)rz in relation to parent material

\begin{tabular}{|c|c|c|c|c|c|c|c|}
\hline Parent material & $\begin{array}{c}\text { Total number } \\
\text { of profiles }\end{array}$ & Loam & $\begin{array}{l}\text { Sandy } \\
\text { loam }\end{array}$ & $\begin{array}{c}\text { Sandy clay } \\
\text { loam }\end{array}$ & $\begin{array}{c}\text { Clayey } \\
\text { loam }\end{array}$ & $\begin{array}{l}\text { Sandy } \\
\text { clay }\end{array}$ & Clayey \\
\hline \multicolumn{8}{|c|}{ Horizon Amo } \\
\hline Massive limestone & 19 & 4 & - & 3 & 4 & - & 8 \\
\hline Dolomitic limestone & 7 & 1 & - & - & 4 & 1 & 1 \\
\hline $\begin{array}{l}\text { Bituminous } \\
\text { limestone }\end{array}$ & 7 & 1 & 1 & - & 5 & - & - \\
\hline Plate limestone & 8 & - & - & 3 & 5 & - & - \\
\hline Dolomitic marbles & 5 & - & 1 & 2 & 1 & 1 & - \\
\hline $\begin{array}{l}\text { Laminated (plate) } \\
\text { dolomiteand calcite }\end{array}$ & 6 & - & - & 3 & 1 & - & 2 \\
\hline \multicolumn{8}{|c|}{ Horizon (B)rz } \\
\hline Massive limestone & 9 & - & - & - & 1 & - & 8 \\
\hline Dolomitic limestone & 4 & - & - & - & 1 & - & 3 \\
\hline $\begin{array}{l}\text { Bituminous } \\
\text { limestone }\end{array}$ & 3 & - & - & - & 1 & - & 2 \\
\hline Plate limestone & 5 & - & - & - & 4 & - & 1 \\
\hline Dolomitic marbles & 1 & - & - & - & - & - & 1 \\
\hline $\begin{array}{l}\text { Laminated (plate) } \\
\text { dolomite and calcite }\end{array}$ & 1 & - & - & - & - & - & 1 \\
\hline
\end{tabular}

The degree the mineralogical composition affects the soil moisture retention depends on the percentage amount and fraction of the clay minerals present in a soil type. The clay particles represent the most active part of the fine earth because of their large external and internal active surface, cation-exchange capacity (CEC) and mineralogical composition.

Many authors, such as Barteli and Peters, Salter et al., Petersen et al. (Markoski 2012), state that the increase in the slightly smaller particles in their quantity increases the surface of tangency between the solid phase and soil moisture.

In addition to the mechanical composition explanation presented before, we studied the influence of the moisture retention, given the different levels of tension in soil (starting with $0.1(\mathrm{pF}-2)$ and going to 15 bar or (pF-4.2), which corresponds to the wilting point). The remaining soil moisture above 15 bars is not available to the plant (Bogdanovic 1973).

According to Filipovski (1996), soil water retention with different tension is in tight correlation with humus, clay and silt content and mineralogical composition of the clay. Maclean and Yager (1972); Jamison and Kroth (1958), Shaykewich and Zwarich (1968) and Heinonen (1971) studied the effect of the organic matter and the mechanical content over the water retention in several soils throughout the U.S. Europe and Asia.

Data for the water capacities of calcocambisols ( $\mathrm{pF} 1 ; \mathrm{pF} 2 ; \mathrm{pF} 2.5 ; \mathrm{pF} 3.5$ and $\mathrm{pF} 4.2$ ) can be found in the researches of González-Pelayo. et al. (2006). 
Table 4. Analysis of variances of soil mechanical composition for the surface Amo and cambic horizon (B)rz

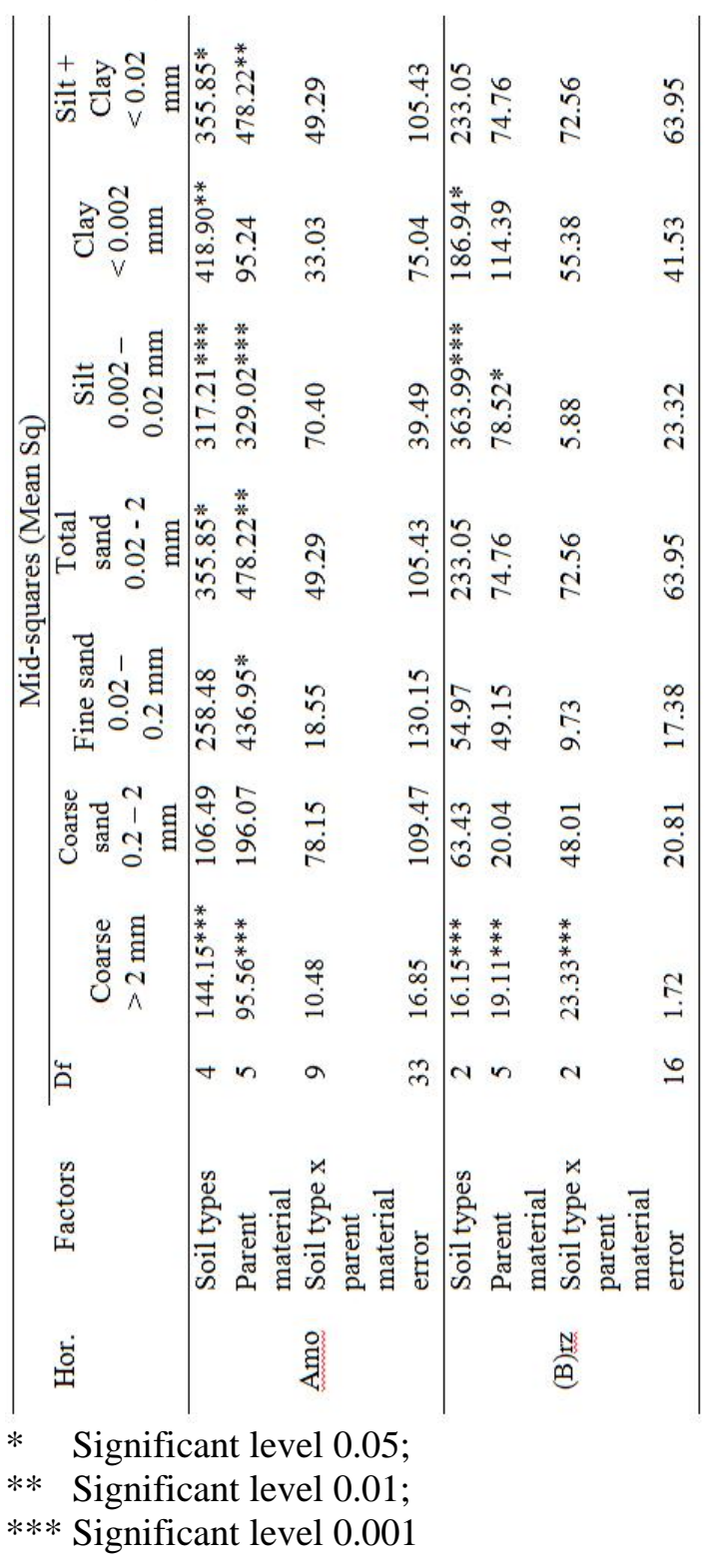

Table 5. Mean values for retention on the horizon Amo

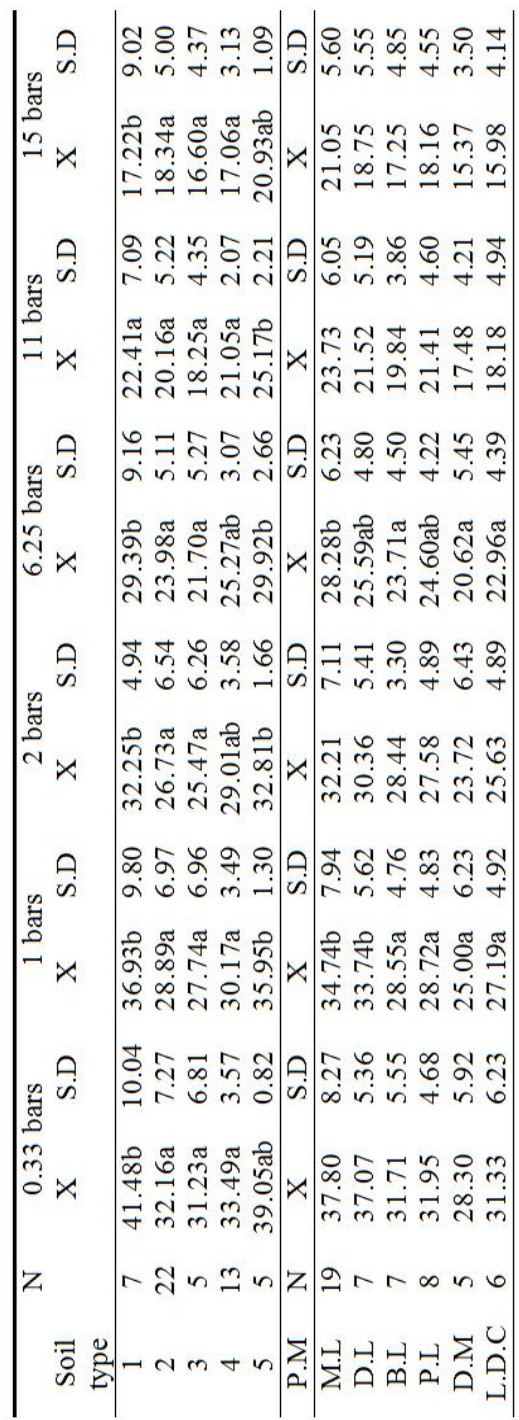

1. Rendzic Leptosols -organogenic; 2. Rendzic Leptosols, haplic; 3. Rendzic Leptosols, chromic luvic; 4. Chromic Luvisol on hard limestones; 5 . Terra Rossa

P.M- Parent material; M.L.-Massive limestone; D.L-dolomitic limestone; B.L- bituminous Limestone; P.L-Plate limestone; D.M. Dolomitic Marbles; L.D.C- laminated (plate) dolomiteand calcite 
Table 6. Mean values for retention on the horizon (B)rz

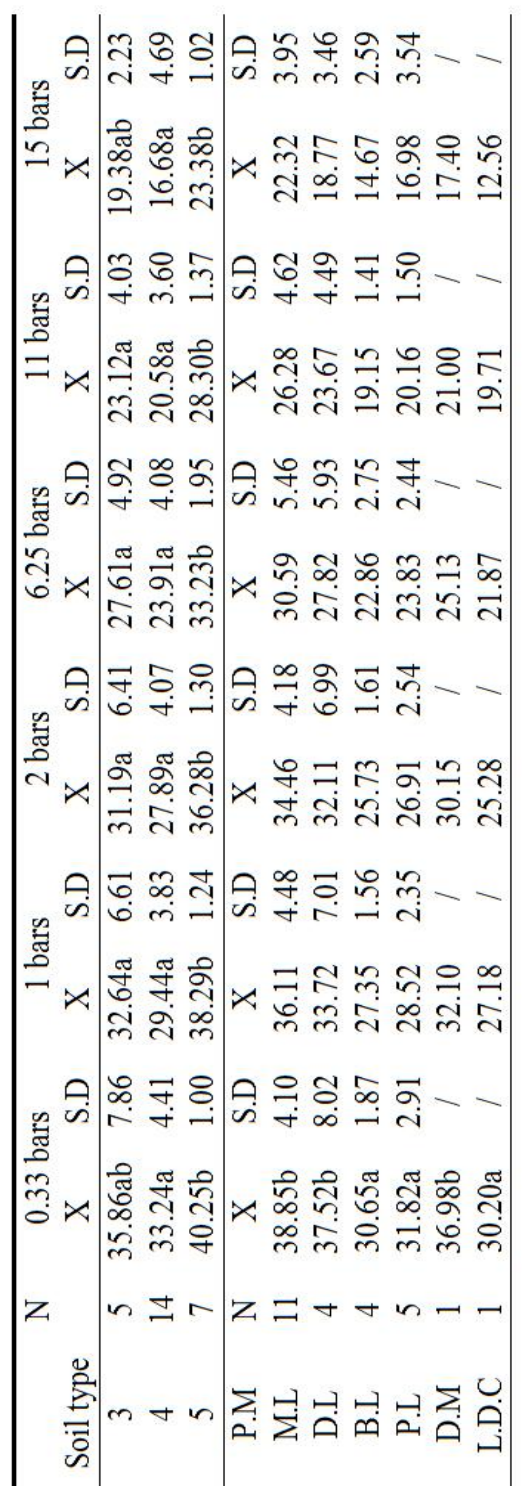

3. Rendzic Leptosols, chromic luvic;

4. Chromic Luvisol on hard

limestones; 5. Terra Rossa;P.M-

Parent material; M.L.-Massive

limestone; D.L-dolomitic limestone;

B.L- bituminous Limestone; P.L-

Plate limestone; D.M. Dolomitic

Marbles; L.D.C- laminated (plate)

dolomiteand calcite
They are dealing with the issue of hydrological constants and the influence of the fires on the retention of Chromic Luvisol on hard limestones around Mediterranean. All profiles of the examined soils were placed on 6 difference pressure regimes $(0.33 ; 1 ; 2 ; 6.25 ; 11 ; 15$ bars $)$. The mean values of moisture, in mass percentages, in Amo and (B)rz horizons are given hereunder in order to have better understanding of the intensity of the moisture retention in the soil types and subtypes. Due to the large content of humus, as well as due to the large content of clay and the high hydrophilicity and the capillary porosity, the soils formed on limestones and dolomites are characterized with high values of water capacities. It can be seen from the Table 5 and 6 that largest retention capacity, of $41.48 \%$ in average, under the pressure of 0.33 bars, is found in the humus accumulative horizon (Amo), in the subtype Rendzic Leptosols organogenic. The other subtypes have lower retention in this horizon, i.e. the Rendzic Leptosols, haplic $32.16 \%$ in average, and the Rendzic Leptosols, chromic luvic, $31.23 \%$ in average, and in the cambic horizon (B)rz at the Rendzic Leptosols, chromic luvic, the retention amounts $35.86 \%$ in average.

The average retention values (pressure of 0.33 bars) in the Amo horizon and the cambic horizon (B)rz at Chromic Luvisol on hard limestones amount $33.49 \%$, i.e. $33.24 \%$.

The greater presence of the small pores, the content of humus and clay, also affects the high moisture retention values under pressure of 6.25 bars. The average retention content under pressure of 15 bars in the Amo horizon in (B)rz amounts $17.06 \%$, and $16.68 \%$ in average. According to Ćirić (1986) despite the heavy mechanical composition, the good water 
permeability of the Chromic Luvisol on hard limestones is due to the favourable structure and the moderate swelling of the soil aggregates. The water infiltration in the soil is slower and it takes more time. The reason for this appearance stems from the higher presence of micro pores within the soil aggregates, and that is why a longer period was necessary to moisturize the soil samples during the analysis of water capacities. This makes the soils dry, especially at a particular constellation of factors (shallow solum, less rainfalls, greater slope field as well as south exposure). Compared with calcocambisols, Terra Rossa has a higher retention capacity in all three tension points $(0.33 ; 6.25$. and 15 bars), Chart 3 .

The average retention in Terra Rossa under pressure of 0.33 bars in the Amo horizon amounts to $39.05 \%$, and in the (B)rz horizon to $40.25 \%$. Under the pressure of 6.25 bars, the retention in the Amo horizon on average amounts to $29.92 \%$; in the (B)rz horizon to $33.23 \%$, and under pressure of 15 bars in the Amo horizon it amounts to $20.93 \%$; in the (B)rz horizon $23.38 \%$ on average. The moisture retention clearly indicates the texture differentiation of the profile: the Amo horizon has the lowest retention and the cambic horizon (B)rz has the highest. Terra Rossa contains high percentage of clay, but unlike in Rendzic Leptosols and Chromic Luvisol on hard limestones, it is joined in stabile structure aggregates under the effect of humus and sesquioxides, due to which the soils show good water permeability, aeration and are warm soils. The Table 7 shows the correlation coefficients between the humus, physical sand and physical clay content and retention in different tension points on both horizons.

Based on the correlation analysis of the Amo horizon, it can be noted that the physical sand has a significant negative correlation with all retention constants $(r=-0.47)$, and a significant negative correlation $(r=-0.21)$ between the humus and physical sand content has also been noted. From the correlation analysis of the (B)rz horizon it can be noted that the humus has a significant negative correlation with the retention constants $(r=-0.49)$, and the physical sand has a small significant negative correlation with retention of $0.33 ; 6.25$ and 11 bars $(r=-0.28 ; r=-0.14$; and $r=-0.04)$. Retention curves can be obtained if the tension of soil moisture is constantly measured and for each tension the moisture quantity is measured, expressed in percentage, and if the data obtained are entered in a coordinate system. They reflect the ratio between the attractive forces (tension) and the amount of soil moisture. Matula et al. (2007) emphasize that soil hydraulic characteristics, especially the soil water retention curve, are essential for many agricultural, environmental, and engineering applications. Their measurement is time-consuming and thus costly. The Charts 1,2 and 3 show retention curves in six different tensions $(0.33 ; 1 ; 2 ; 6.25 ; 11$. and 15 bars) for soil testing. From the charts on retention curves of soils formed over limestones and dolomites it can be noted that the soil retention is very high in all three soil types, due to the high content of humus and clay. Chart 1 shows the retention curves for three subtypes of Rendzic Leptosols and it can be noted that the retention curve in the Rendzic Leptosols organogenic subtype is highest which is due to the higher content of humus in this subtype as well as the content 
Table 7. Correlation coefficients between the tension points of $0.33 ; 1 ; 2 ; 6.25$; 11; 15 bars and humus, physical sand and physical clay content in the Amo and (B)rz horizons

\begin{tabular}{|c|c|c|c|c|c|c|c|c|c|}
\hline Hor. Amo & $\begin{array}{c}\text { Organic } \\
\text { matter }\end{array}$ & $\begin{array}{l}\text { Total } \\
\text { sand }\end{array}$ & $\begin{array}{l}\text { Silt+ } \\
\text { clay }\end{array}$ & $\begin{array}{l}0.33 \\
\text { bars }\end{array}$ & $\begin{array}{c}1 \\
\text { bars }\end{array}$ & $\begin{array}{c}2 \\
\text { bars }\end{array}$ & $\begin{array}{l}6.25 \\
\text { bars }\end{array}$ & $\begin{array}{c}11 \\
\text { bars }\end{array}$ & $\begin{array}{c}15 \\
\text { bars }\end{array}$ \\
\hline Organic matter & 1 & 0.21 & -0.21 & 0.12 & 0.12 & 0.18 & 0.01 & 0.03 & 0.16 \\
\hline Total sand & 0.01 & 1 & -1 & -0.47 & -0.46 & -0.32 & -0.42 & -0.41 & -0.35 \\
\hline Silt+clay & -0.01 & -1 & 1 & 0.47 & 0.46 & 0.32 & 0.42 & 0.41 & 0.35 \\
\hline 0.33 bars & -0.38 & -0.28 & 0.27 & 1 & 1 & 0.90 & 0.95 & 0.93 & 0.89 \\
\hline 1 bars & -0.49 & 0.01 & 0.15 & 0.98 & 1 & 0.91 & 0.95 & 0.93 & 0.89 \\
\hline 2 bars & -0.39 & -0.14 & 0.14 & 0.97 & 0.99 & 1 & 0.88 & 0.88 & 0.84 \\
\hline 6.25 bars & -0.44 & 0.06 & 0.06 & 0.90 & 0.97 & 0.96 & 1 & 0.99 & 0.93 \\
\hline 11 bars & -0.44 & -0.04 & 0.04 & 0.89 & 0.96 & 0.96 & 0.99 & 1 & 0.95 \\
\hline 15 bars & -0.39 & 0.19 & 0.19 & 0.73 & 0.84 & 0.87 & 0.88 & 0.87 & 1 \\
\hline
\end{tabular}

*The correlations in the upper part of the table refer to the Amo horizon, and in the lower part refer to the (B)rz horizon.

of physical clay. The retention curves in Rendzic Leptosols, haplic and Rendzic Leptosols, chromic luvic is almost parallel in all points of tension. All three curves are almost horizontal with a small decrease in brownised calcomelanosols in tension of 15 bars.

Chart 2 shows the average values of retention curves in Chromic Luvisol on hard limestones. It can be seen that Chromic Luvisol on hard limestones have high retention in all points of tension and do not have a big slope of soil moisture. Also, it can be noted that retention curves with tension of 11 and 15 bars are almost identical. The small difference between retention curves is the result of combined effect from clay, humus and mineral composition of clay.

In the Terra Rossa (Chart 3) retention curved are high, which means that there is high moisture retention (high content of clay, humus). The mineral composition of clay, according to depth of profile, is the same which means that the retention depends on the clay content: the differences in retention between different horizons follow the clay content.

The fall of retention curves from lower to higher tensions is small, which means that a good portion of the water is not held by a great force by the soil particles and is more easily freed from them. The texture differentiation is clearly reflected in the moisture retention: the Amo horizon has the lowest retention, which contains less physical clay, and the cambic horizon (B)rz has higher retention since it contains more physical clay. From the soil retention curves formed upon limestones and dolomites a gradual change in retention forces is noted with the change of moisture without jumps. 


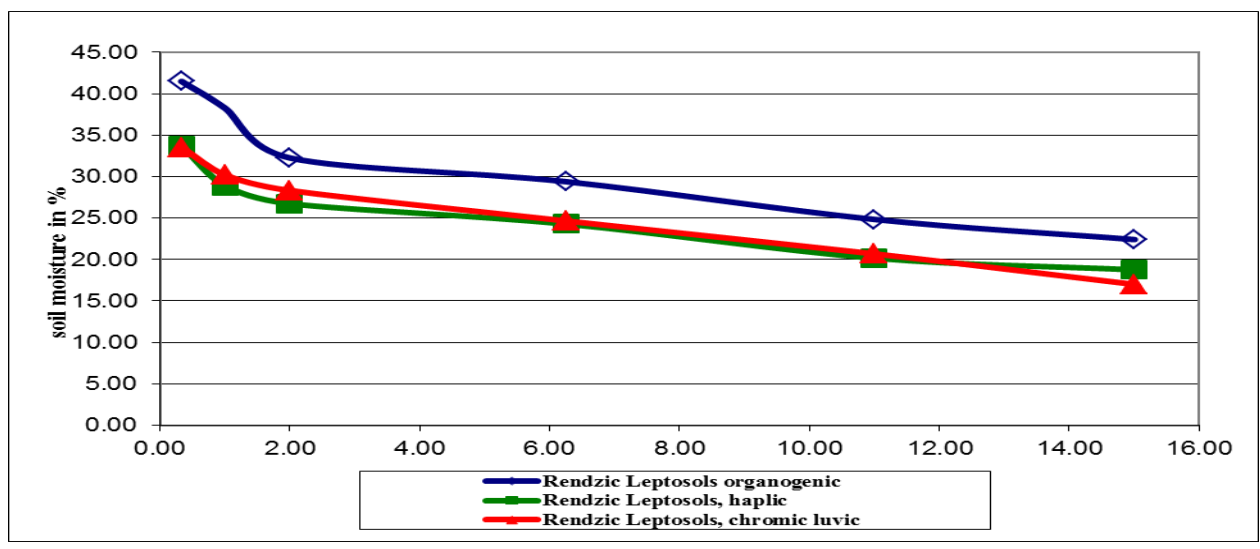

Chart 1. Retention curves of soil moisture in subtypes of Rendzic Leptosols in the Amo horizon

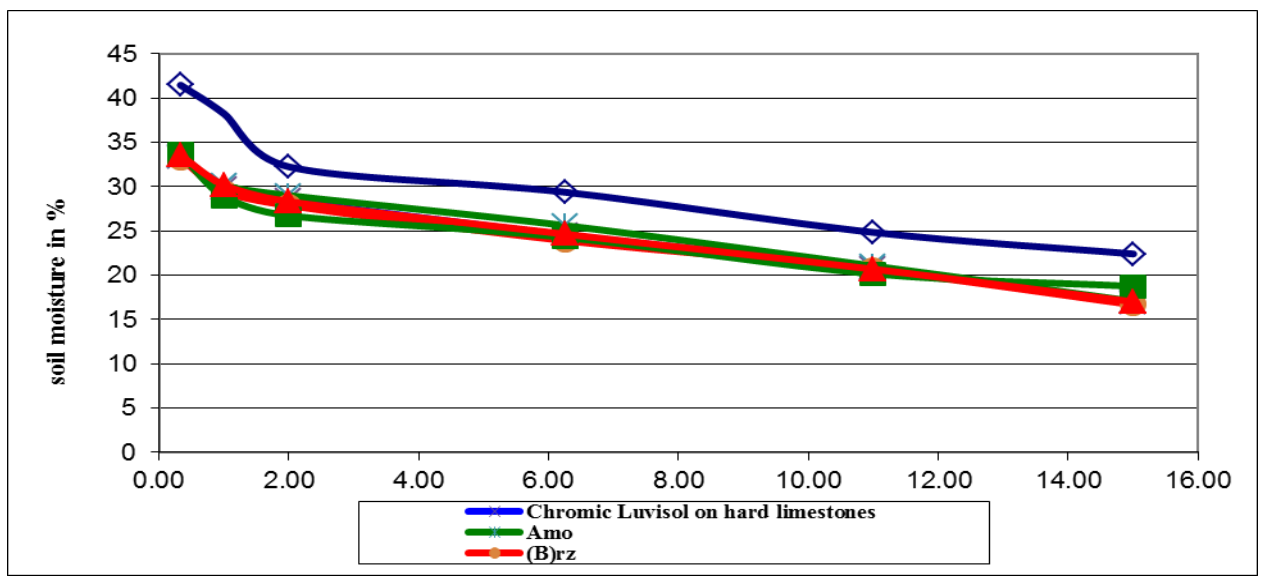

Chart 2. Retention curves of soil moisture in Chromic Luvisol on hard limestones

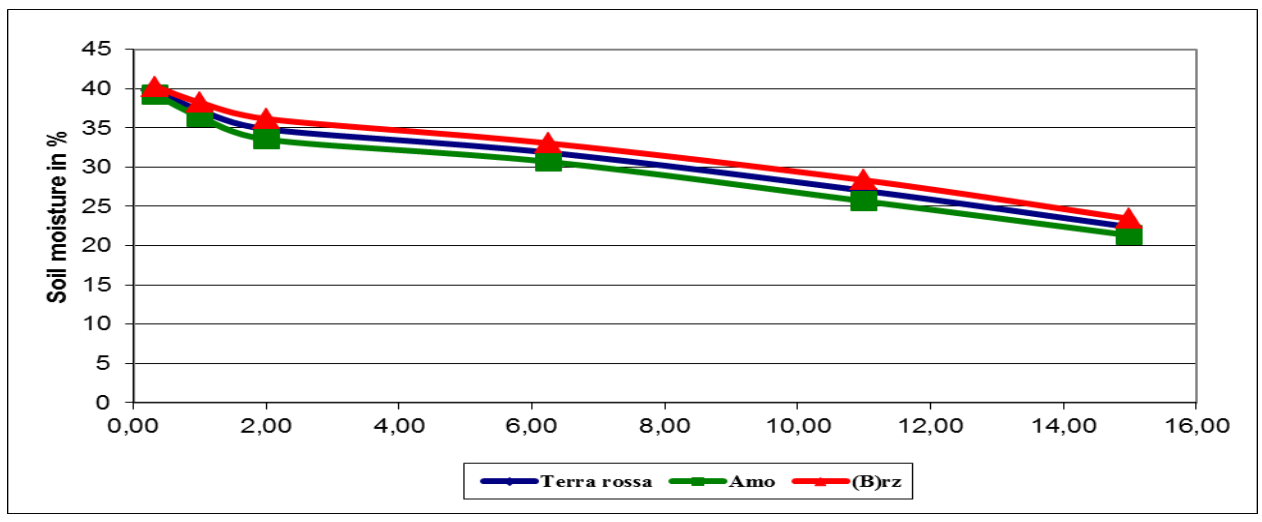

Chart 3. Retention curves of the soil moisture in Terra Rossa 
Table 8. Analysis of variances of retention curves of soil moisture for the surface Amo and cambic horizon (B)rz

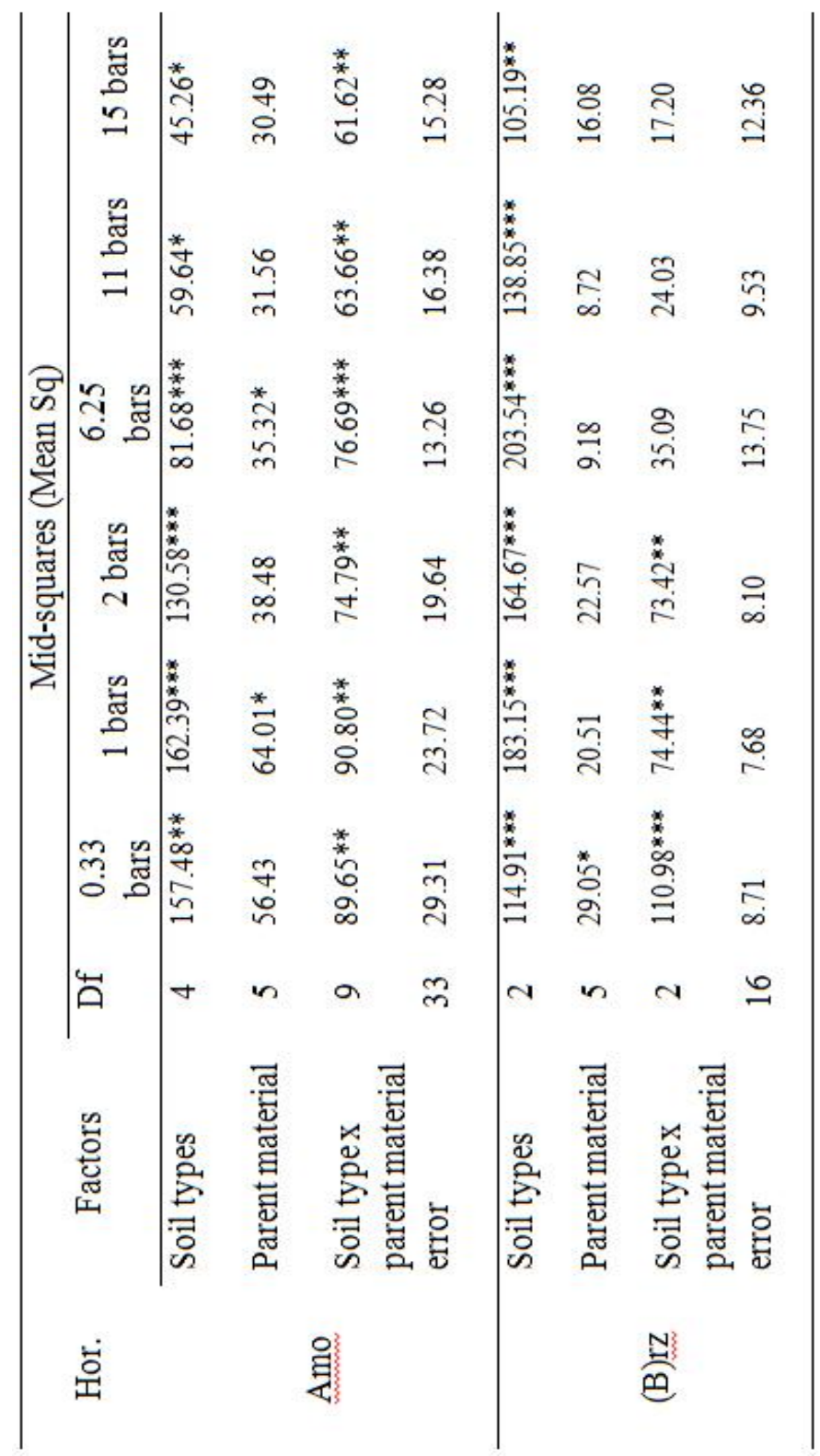

This indicates that the division of soil moisture into various forms is not justified in the retention curve, since the reduction of the water quantity does not have great jumps in different tensions.

The impact of subsoil and soil type on the retention of soil moisture at all points of tension can be seen from the analysis of variance Table 8. It showed 
that soil type has a significant impact on the variability of the retention of moisture and at all points of tension and in both horizon. Subsoil similar soil type has a significant impact on retention in Amo horizon and at the points of tension of 1 bar, 6.25 bars, and only subsoil has a significant influence on the horizon (B)rz on the retention of soil moisture at a pressure of 0.33 bar.

\section{CONCLUSIONS}

The variance analysis has shown that in both horizons, the soil type has significant effect over the variability of the coarse, silt and total clay content. In the humus accumulative horizon Amo, the soil type also has effect over the physical sand fraction and the physical clay fraction. The parent material in both horizons affects the coarse and silt content variability, and in the Amo horizon it also affects the physical sand and physical clay content. In relation to the effect of the material (Table 4) it can be noted that in the Amo horizon there is the least coarse in the soils formed upon massive limestone (5.79\%), value that statistically significantly differs from the soils formed upon dolomitic marbles and laminated (plate) dolomite and calcite (14.52 and 14.79\%).

The effect of the remaining substrates does not significantly deviate in relation to the lowest and highest values on the content of this fraction. In the cambic horizon (B)rz, the lowest coarse content is present in massive limestone $(1.11 \%)$, in dolomitic limestone (1.03\%) and in bituminous limestone $(0.94 \%)$ which significantly statistically differ from dolomitic marbles $(8.15 \%)$ and plate limestone $(4.79 \%)$.

There is no statistically significant difference in the effect of the substrates for the coarse sand fraction, but there is a difference for the fine sand fraction. This fraction is the least present in the Amo horizon in soils formed upon massive limestone $28.41 \%$ and dolomitic limestone $23.79 \%$ compared to dolomitic marbles 49.39\%. Unlike the Amo horizon, in the cambic horizon (B)rz there is no statistically significant difference for this fraction. The physical sand fraction has the lowest presence in the Amo horizon in soils formed upon dolomitic limestone $(28.71 \%$ ), which statistically significantly differs from those formed upon dolomitic marbles which have the highest value for this fraction $(53.88 \%)$. Similarly as for the previous fraction, the physical sand fraction in the cambic horizon (B)rz also has no significant difference in relation to the substrates on which the soils have formed.

For the physical clay fraction (silt + clay) there is only a statistically significant difference in the silt fraction in both horizons. In the Amo horizon, there is the smallest and approximate value in soils formed on dolomitic marbles $(15.86 \%)$ and laminated (plate) dolomite and calcite (15.93\%) and there is the highest average value in soils formed on bituminous limestone $(32.86 \%)$ and dolomitic limestone (37.76\%). The physical clay fraction has the lowest average value in soils formed upon dolomitic marbles (46.12\%) and the highest average value in soils formed upon dolomitic limestone (71.29\%). A lower statistically significant value is noted in soils formed upon massive limestone (64.83\%) and 
bituminous limestone $(62.06 \%)$. The is no statistically significant difference in the cambic horizon (B)rz for this fraction.

Texture of the tested soil is characterized by the predomination of the physical clay and clay separates in the fine earth that strongly influences the soil moisture retention curves.

The amount of moisture that is retained in the soil at the pressure of 0.33 bars is high in all horizons.

The data that were obtained for a wilting point (pressure of 15 bars) are high in all horizons for all the tested sample soil. This is the result of a high content of clay in soil separates.

The results from our research show that in Amo and (B)rz horizon there is a positive correlation between the water retention curves at $0.33 ; 6.25$ and 15 bars and contents of physical clay (clay and silt) and clay. Also there is high negative correlation between the retention curves at $0.33 ; 6.25$ and 15 bars contents of physical sand fraction (coares+fine sand), $r=-0.47$.

\section{REFERENCES}

Bogdanović, J. (1973): Usporedna ispitivanja metoda za određivanje vlažnosti venuća kod različitih tipova tala. Zemljište i biljka, Vol 22, $\mathrm{N}^{\mathrm{o}} 3$.

Bronger, A., Smolíková, L. (1981): Herkunft der Terrae calcis in der Slowakei. Věstnikûstŕ Geolog. 56, p. p. 145 - 156.

Bronger, A., Ensling, J., Gütlich, P., Spiering, H. (1983): Rubification of terrae rossae in Slovakia: a Mösbauer effect study. Clays Clay Miner. 31, p.p. $269-276$.

Borg, L. E. and Banner, J. L. (1996): Neodymium and strontium isotopic constraints on soil sources in Barbados, WestIndies. Geochim. Cosmochim. Acta 60, p. p. 4193 $-4206$.

Bormann. H. (2007): Analysis of the suitability of the german soil texture classification for the regional scale application of physical based hy-drological model. Advances in Geosciences, 11. p.p. 7-13.

Christopher T.B.S. and Mokhtaruddin A.M. (1996): A computer program to determine the soil textural class in 1-2-3 for windows and excel.Commu-nications in Soil Science and Plant Analysis, 27(9 and 10):2315-2319.

Coquet Y., Vachier P., and Labat C. (2005): Vertical variation of near-saturated hydraulic conductivity in three soil profiles. Geoderma, 126, p.p.181-191.

Coric, R. (2009): Adsorpciske značajke crveničnih tala na karbonatnim sedimentima. Sveučilišta u Zagrebu. Agronomski fakultet Zagreb. str. 1 - 126.

Durn, G., Ottner, F., Slovenec, D. (1999): Mineralogical and geochemical indicators of the polygenetic nature of Terra Rossa in Istria, Croatia. Geoderma. 91. p. p. 125 -150 .

Durn, G. (2003): Terra Rossa in the Mediterranean region: Parent materials, composition and origin. Geologia Croatica. Zagreb. 56/1 str. $83-100$.

Delgado, R., Martín - Garicía, J. M., Oyonarte, A. C., Delgado, G. (2003): Genesis of the terrae rossae of the Sierra Gádor (Andalusia, Spain). European Journal of Soil Science, March. 54, p.p. $1-16$.

FAO - UNESKO. (1988): Soil map of the World. Revised legend. FAO. Rome.

Filipovski, G. (1996): Soil of the Republic of Macedonia. Macedonian Academy of Sciences and Arts. Skopje. Vol II. p.p. $11-55$. 
González - Pelayo, O., Andreu, J. V., Campo, B. E., Gimeno - García, J., Rubio, L. (2006): Hydrological properties of a Mediterranean soil burned with different fire intensities. Catena 68. p.p. $186-193$.

Heinonen, R. (1971): Soil management and crop water supply. Lantbruk - shögskolans kompendienämnd.

Hollis, J. M., Jones, R. J. A., Palmer, R. C. (1977): The effects of organic matter and particle size on the water retention properties of some soil in the west Midland of England. Geoderma. 17. p. p. 225-238.

Hillel, D. (1980): Application of Soil Physics. Department of Plant and Soil Sciences. Massachusetts, Academic press. p. p. $1-413$.

Hillel, D. (1998): Environmental Soil Physics. Academic Press, San Diego-London-New York-Tokyo.

Jamison, V. C., Kroth E. M. (1958): Available moisture storage capacity in relation to textural composition and organic content of several Missouri soils. Soil Sciences. Am. Poc. 22. p.p. 189-192.

Jackson, M. L., Clayton, R. N., Violante, A., Violante, P. (1982): Eolian influence on Terra Rossa soils of Italy traced buy quartz oxygen isotope ratio. Int. Clay Conf. 7 th, p.p. $293-301$.

Kochkin, M. A. (1967): Soils, Forests and the Climate of the Mountainous Crimea and the Ways of Their Rational Utilization. Kolos. p.p. 272-274.

Kutilek, M., Nielsen, D. (1994): Soil Hydrology. Geo Ecology. Catena Verlag, Cremlingen-Destedt, Germany.

Kadam, J. R., Shinde P. B. (2005): Practical Manual on Soil Physics- A method manual, Department of Agricultural Chemistry and Soil Science, P.G.I., Rahuri, p.p. 8.

Livingston, N. J. (1993): Soil water potential. Soil sampling and methods of analysis. Canadian Society of Soil Sciences. p.p. 559-567.

Marić, L. (1964): Terra Rossa u karstu Jugoslavije. Jugoslovenska akademija znanosti i umetnosti. Zagred. Acta Geologica JAZU 4. p.p. 19 - 72.

Maclean, A. H. and Yager, T. V. (1972): Available water capacities of Zambian soils in relation to pressureplate measurments and particle size analysis. Soil Sciences. 113.p.p. 23-29.

Meada, T. Warkentin, B. P., (1975): Void changes in allophane soils determining water retention and transmission. Soil Sciences. Am. Proc. 398-403.

Mizota, C., Kusakabe, M. and Noto, M. (1988): Eolian contribution to soil development on Cretaceous limestones in Greece as evidenced by oxygen isotope composition of quartz. Geochem. J. 22. p. p. 41-46.

Matula S., Mojrová M., Špongrová K. (2007): Estimation of the soil water retention curve (SWRC) using pedotransfer functions (PTFs). Soil \& Water Res., 2 113122

Muhs, D. R. and Budahn, J. R. (2008): Geochemical evidence for African dust and volcanic ash inputs to Terra Rossa soils on carbonate reef terraces, northern Jamaica, West Indies. Quaternary Int. doi:10.1016/j.quaint. 2007.10.026.

Markoski, M., Mitkova, T. 2012: Soil moisture retention changes in terms of mineralogical composition of clays phase. Clay Minerals in Nature - Their characterization, modification and application. Publisher, InTech. p.p. $101-$ 119.

Markoski, M. (2013): Genesis and properties of soil formed upon lime stones and dolomites in the Republic of Macedonia. Doctoral disetation. Faculty of Agricultural Sciences and Food. Skopje. p.p. 1-163. 
Plaster, R.W., Sherwood, W.C. (1971): Bedrock weathering and residual soil formation in Central. Virginia. Geol. Soc. Am. Bull. 82, p. p. 2813 - 2826.

Rousseaux, J. M., Warkentin, B. P. (1976): Surface properties and forces holding water in allophane soils. Soil Sciences Am. Proc. 40. p. p. 446-451.

Shaykewich, C. F. Zwarich, M. A. (1968): Relationships between soil physical constants and soil physical components of some Manitoba soils. Can. J. Soil Sciences. 48. p.p. 199-204.

Singh, Dhyan, Chhonkar, P. K. and Pande, R. N. (1999): Soil Testing in Soil, Plant, Water Analysis, Methods Manual IARI, ICAR, New Delhi, 1, p.p. 6-11.

Vučić, N. (1987): Vodni, vazdušni i toplotni režim zemljišta, VANU. Matica srpska. Novi Sad, p. 1 - 320.

Warkentin, B. P., Meada, T. (1974): Physical properties of allophane soils from the West Indies and Japan. Soil Sciences. Am. Proc. 39. p.p. 372-377.

WRB - World Reference Base for soil resources. (2006): Diagnostic Horizons, Properties and Materials. Chapter 3.World Reference Base for Soil Resources. FAO, ISSSAISS-IBG, IRSIC, Rome, Italy. p.p. 1 - 128.

Yaalon, D. H. and Ganor, E. (1973): The influence of dust on soils during the Quaternary. Soil Scie. 116, p. p. 146 - 155. 